\title{
COMPARISON OF OPTIMAL COSTS OF AXIALLY LOADED RC TENSION MEMBERS USING INDIAN AND EURO STANDARDS
}

\author{
N.KARTHIGA ALIAS SHENBAGAM', N.ARUNACHALAM²
}

Abstract: The aim of this study is to find the cost design of RC tension with varying conditions using the Artificial Neural Network. Design constraints were used to cover all reliable design parameters, such as limiting cross sectional dimensions and; their reinforcement ratio and even the beahviour of optimally designed sections. The design of the RC tension members were made using Indian and European standard specifications which were discussed. The designed tension members according to both codes satisfy the strength and serviceability criteria. While no literature is available on the optimal design of RC tension members, the cross-sectional dimensions of the tension membersfor different grades of concrete and steel, and area of formwork are considered as the variables in the present optimum design model. A design example is explained and the results are presented. It is concluded that the proposed optimum design model yields rational, reliable, and practical designs.

Key Words: RC tension members, optimal design, optimization, loadings, neural networks, design model, Indian standards, Euro standards.

\section{INTRODUCTION}

Reinforced concrete structures are ones made of two or more different materials:-, minimum weight has no meaning with respect to optimization. Optimization has been formulated as minimum cost. Large number of papers have been published on optimization of structures. However, only a small fraction of these deal with cost optimization of structures. For concrete structures, the objective function to be minimized should be cost, since they are made of more than one material. Tie members of trusses and tied arches, walls of rectangular tanks and bunkers, suspended roofs, cylindrical pipes, and walls of liquid retaining structures are some of the sample problems where tensile stresses develop. Traditional elastic approach and the limit state method can be useful for the design of such structures. Based on the elastic theory, the classical method is straight - forward in concept and application, while the limit state method, based on cracking behaviors of concrete, is not yet fully developed. IS 456:2000 and Euro codal specifications give due considerations for compression either direct or connected with bending and shear when the limit state method is working. However, it is silent on tension members. Therefore the working stress method is employed in this paper to explain the design of such members.

\footnotetext{
${ }^{1}$ Assistant professor, B.E (Civil), M.E (Structures) Bannari Amman Institute of Technology, Faculty of Civil Engineering, Sathyamangalam, Erode District, India

${ }^{2}$ Prof, B.E (Hons), M.Sc (Engg), Bannari Amman Institute of Technology, Faculty of Civil Engineering, Sathyamangalam, Erode District, India
} 


\section{TENSION MEMBERS}

Vertical suspenders in a bowstring girder and the-, ring beam of a dome are some of the members subjected to direct tensile forces. Many RC structural components such as walls of water tanks, bunkers, silos, and counter forts of retaining walls are subjected to tensile force, in addition to bending moments.

\section{PREVIOUS LITERATURE}

Abobakr A.A.Aga, Fathelrahman M.Adam ${ }^{[1]}$ (2015) in their paper explain the formation of objective function for a frame in a detailed manner with the various constraints for each and every element in a frame, and optimization is done with the help of ANN.-, The cost compared is the actual manually calculated one with that of ANN, the difference between them is discussed and it is found that ANN gives a better result than the manual design.

Anand Prakash. S.K. Agarwala..K.K. Singh ${ }^{[2]}$ (1988) explain the optimal design considerably in a simplified manner, handling the cost ratio of steel-to-concrete as a variable. The authors have adopted this approach using modern computers, software and relatively simple optimization techniques to obtain optimum design results for singly and doubly--reinforced beams, T-beams, and columns, which are eccentrically loaded and the results and conclusions are then described in a detailed manner.

ArunlfoLuevanos-Rojas $(2016)^{[3]}$, in their paper demonstrated the optimal design of the Singly Reinforced Beam by creating a model and an analytic approach using ACI-318, considering two criteria, with four different cases for minimum weight (Case 3,4) and minimum cost (Case 1,2) and it is concluded that for Case 1 the optimum section is very economical compared to other sections that may be obtained using the standard design method. The optimum steel ratio is usually smaller than the maximum ratio, pmax, and greater than minimum ratio, pmin. Cases 2, 3 and 4: The optimum steel ratio is equal to the maximum ratio pmax.If we analyze the mathematical results of the standard design method and the optimal design method, they are equal.

S.A.Bhalchandra, P.K.Adsul ${ }^{[4]}$, (2012) in their paper explained the design of simply supported doubly reinforced beam with two types of loadings and the optimal cost solution is determined, in addition to the serviceability conditions, with the help of the GRG approach and MATLAB.

Luisa Maria Gil Martin and Enrique Hernandez ${ }^{[1]}(2010)$ in their research work explain the optimal positioning of the reinforcement area with the help of the latest computing tools, considering the effect of the constraints with a suitable example which has bars on both sides, it saves the cost of construction and improves the durability of structural construction. 
Chakrabarty-(1992) ${ }^{[5]}$ in his paper made use of geometric programming and found the optimal design of singly-reinforced rectangular concrete beams. The design variables considered are the cross-section of the beam and the area of steel reinforcement. The main objective function was the total cost of construction of the beam. He included the strength aspects in the design process for bating optimal or minimal values but discounted the ductility and side constrains.

G Preethi and Prince G Arulraj ${ }^{[7]}$ in their paper regarding different grades of concrete and steel, determined the optimal total cost of the RC column by the use of MATLAB programming using the fmincon SQL algorithm and found it to be a very effective approach for determining optimal design.

N.S.Hadi ${ }^{[8]}(2002)$ in his paper gives a brief description about the application of ANN and the different kinds of methods we can use and implement in structural engineering problems.

H.Sudarshana Rao and B. Ramesh Babu, (2006) ${ }^{[9]}$, in their paper demonstrate the design of short columns under biaxial bending with use of optimization techniques. In this paper, they used ANN and GA. The results of biaxial columns are optimized by modified GA, the outputs are compared and it is observed that the maximum difference between both methods is only $1.6 \%$. The conclusion is then made that a developed neural network model can provide a safe and economical outline for the design of short columns under biaxial bending.

ImaRahmanian,YvesLucet, and Solomon Tesfamariam (2014) ${ }^{[10]}$ in their paper describe the review of optimal design of a RC beam by using various optimization techniques and a nonlinear approach is determined which gives suitable, appropriate results.-, It is then checked against the manual design in Excel, which gives a contribution of various design parameters to the overall cost of RC beams.

Luisa Maria Gil Martin - Enrique Hernandez ${ }^{[11]}$ (2010) in their research work explain about the optimal positioning of the reinforcement area with the help of latest computing tools, considering the effect of the constraints with a suitable example which has bars on both sides:-, it saves on the cost of construction and improves the durability of structural construction.

GebrailBekdas, SinanMelihNigdeli (2012) ${ }^{[12]}$ in their paper decsribe the optimization ofbeams using HS and BA approaches respectively, and it is finally concluded that if the flexural moment is 300 $\mathrm{kNm}$ or more, doubly reinforced design is needed. The HS approach is not effective for $400 \mathrm{kNm}$ and $450 \mathrm{kNm}$ flexural moments, because reinforcements are placed in two lines at the compressive section of the beam. Optimum reinforcements placed in a single line were found for the BA and TLBO approaches. Population based methods such as BA and TLBO are effective on the optimum solution of the problem. As a conclusion, TLBO is a competitive algorithm for the optimum design 
of RC beams. Comparing to BA, TLBO is more on finding an optimum solution, and it is easy to apply.

Sinan Melih Nigdeli, Gebrail Bekdaş $(2016)^{[13]}$ in their paper demonstrate the preliminary design of RC continuous beams using ACI-318, from which the optimal cross--sections of beams are acheived by using a random search technique, which in turn minimizes the cost of materials used in the construction of continuous beams. It has been explained that the random search technique gives an effective solution when compared with the other available techniques.

R. Deepan. et.al, March (2016) ${ }^{[14]}$, state in their paper that the optimal design of RC beams is carried out with two loading conditions, for central pointed load and for udl. The designs of the beams and the constraints for optimal design have been carried out using the recommendation of IS456:2000. Manually, the design has been done using MS Excel and verified using Non-traditional Optimization techniques, and it is concluded that use of optimization techniques gives $98 \%$ optimal results (over classical methods).

\section{DESIGN OF A RC MEMBER SUBJECTED TO AXIAL TENSION ONLY}

The following criteria are :

1. The total tension force is considered to be resisted by the reinforcement only.

2. The tensile stress in the reinforcement must be less than or equal to the allowable stress The allowable stress in concrete of the transformed section must be less than or equal to the allowable tensile stress to prevent excessive cracking as given in Clause B-2.1.1 of

Annexure B of IS456:2000

These criteria may be expressed as follows

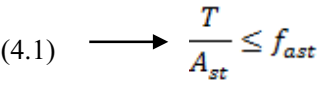

(4.2)

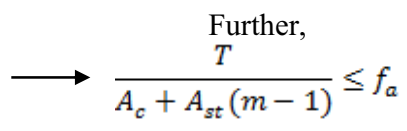

where

T-axial tension face

$\mathrm{A}_{\mathrm{st}}$-area of steel reinforcement

$\mathrm{A}_{\mathrm{c}}$-area of concrete

$f_{\text {ast- }}$ allowable tensile stress in steel

$\mathrm{f}_{\mathrm{a}-}$ allowable direct tensile stress in concrete 


\subsection{DESIGN VARIABLES:}

The design example illustrated below gives the step by step procedure for the RC design of a tension member with respect to the working stress method as per codal provisions of IS456:2000.The grades of concrete used for the design are M25, M30, M35, M40, M45, M50 and steel of grades $\mathrm{Fe}_{250}, \mathrm{Fe} 415, \mathrm{Fe}_{500}, \mathrm{Fe}_{550}$ resp in the case of IS code. In the case of Euro code, the grades of concrete used for the design are M25, M30, M35, M40, M45, M50 and steel of grades $\mathrm{Fe}_{235}, \mathrm{Fe}_{275}, \mathrm{Fe}_{355}, \mathrm{Fe}_{420}, \mathrm{Fe}_{460}$ resp. In both the cases the live loads used are 50kN, 100kN, 150kN and $200 \mathrm{kN}$.

\subsection{WORKING STRESS METHOD:}

Design a tie member of a RCC structure subjected to a tensile force of $100 \mathrm{kN}$ including dead and imposed loads. Assume $\mathrm{M}_{35}$ grade concrete and $\mathrm{Fe}_{250}$ steel.

$\mathrm{f}_{\text {ast-140MPa }}$

$\mathrm{f}_{\text {act- }}-4 \mathrm{MPa}$ (as per IS 456:2000)

(4.3) $\longrightarrow \quad$ Modular ratio $=\mathrm{m}=\frac{280}{3 \sigma_{c b c}}=6.76$

STEP1: Calculation of $\mathrm{A}_{\mathrm{st}}$ required:

The required area of tension reinforcement

(4.4) $\longrightarrow \quad A_{s t}=\frac{T}{f_{\text {ast }}}=\frac{100 * 1000}{140}=714.28 \mathrm{~mm}^{2}$

STEP 2: Calculation of gross area of concrete section:

(4.5)

$$
\begin{aligned}
& \frac{T}{A_{g}+(m-1) A_{s t}} \leq f_{a c t} \\
& \frac{T}{f_{a c t}}-(m-1) A_{s t}=A_{g}
\end{aligned}
$$

(4.6)

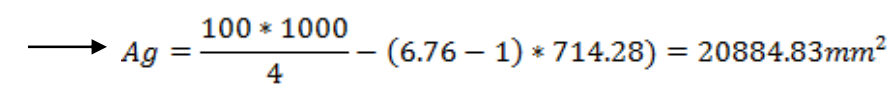

Required theoretical section is of size $144.5 \mathrm{~mm}$ by $144.5 \mathrm{~mm}$. 


\section{ARTIFICIAL NEURAL NETWORK}

The objective function is to minimize the cost per unit length of the tension which is determined as

Total Cost $=$ Cost of Concrete + Cost of Steel + Cost of Formwork

$$
\text { Total Cost }=\mathrm{C}_{\mathrm{c}} \mathrm{A}_{\mathrm{c}}+\mathrm{C}_{\mathrm{s}} \mathrm{A}_{\mathrm{ast}}+\mathrm{C}_{\mathrm{f}} * \mathrm{~A}_{\mathrm{f}}
$$$$
\text { Total Cost }=\mathrm{C}_{\mathrm{c}}\left(\mathrm{A}_{\mathrm{g}}-\mathrm{A}_{\mathrm{st}}\right)+\mathrm{C}_{\mathrm{s}} \mathrm{A}_{\mathrm{st}}+4 \mathrm{C}_{\mathrm{f}} \mathrm{b}
$$

$\mathrm{A}_{\mathrm{g}}$ and $\mathrm{A}_{\mathrm{st}}$ are expressed in $\mathrm{m}^{2}$ units and $\mathrm{b}$ in meter units

where,

$\mathrm{C}_{\mathrm{c}}$-Cost of concrete per unit volume $\left(\mathrm{Rs} / \mathrm{m}^{3}\right)$

$\mathrm{C}_{\mathrm{s}}$-Cost of steel per unit volume $\left(\mathrm{Rs} / \mathrm{m}^{3}\right)$

$\mathrm{C}_{\mathrm{f}}$-Cost of formwork per unit contact area $\left(\mathrm{Rs} / \mathrm{m}^{2}\right)$

$\mathrm{A}_{\mathrm{f}}$-Area of formwork in $\mathrm{m}^{2}$

b- size of square cross section in $m$

The optimization problem is to determine $A_{g}$ and $A_{s t}$ to minimize equation (5.1). The problem is solved for different values of $f_{y}, f_{c k}$, and $T$ to build a database through which the neural network is trained, validated and tested in the following phase of the work.

\section{NEURAL NETWORK MODELS FOR OPTIMUM DESIGN OF RC TENSION MEMBERS}

Five Hundred RC tension members were designed using the two codal provisions, and the total cost (including the cost of formwork per unit length) of members has been estimated. The design has been carried out with three different numbers of hidden layers, the results tabulated, and finally concluded in the discussion is the best optimal solution. 
NEURAL NETWORK MODEL I

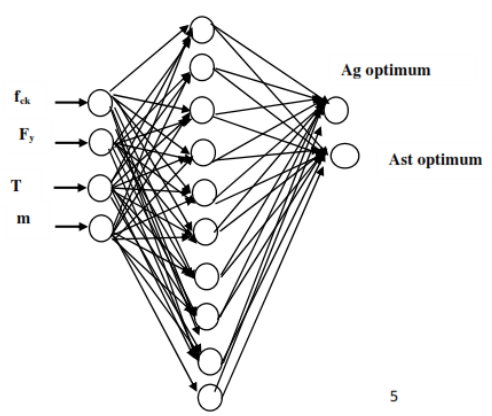

Fig. 1. Neural network model with ten nodes

\section{NEURAL NETWORK MODEL -II}

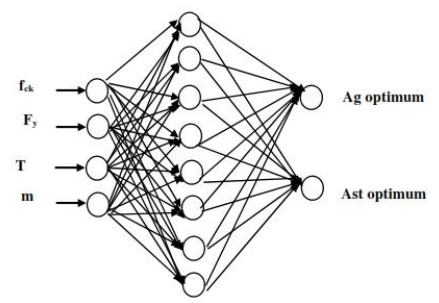

Fig. 2. Neural network model with 8 nodes

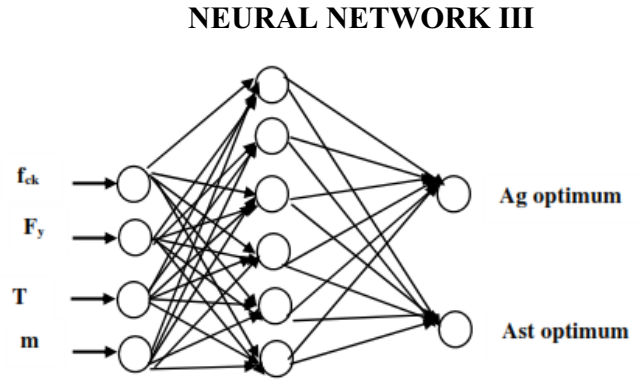

Fig. 3. Network model with six nodes 


\subsection{TEST PROBLEMS}

The test result problems obtained from the different hidden layers are tabulated in the table with some samples, and they are compared with the actual results of the tension member design by using the Indian standards and the Euro Code Standards.

Table1: Results obtained from actual and neural network model

\begin{tabular}{|c|c|c|c|c|c|c|c|c|c|c|}
\hline \multirow{2}{*}{$\begin{array}{c}\text { SI } \\
\text {. } \\
\mathbf{N} \\
\text { o. }\end{array}$} & \multirow{2}{*}{ Inputs } & \multirow{2}{*}{$\begin{array}{c}\text { Theore } \\
\text { tical } \\
\text { Result }\end{array}$} & \multicolumn{3}{|c|}{$\begin{array}{l}\text { Network Output IS } \\
\text { Code }\end{array}$} & \multirow{2}{*}{ Inputs } & \multirow{2}{*}{$\begin{array}{c}\text { Theoreti } \\
\text { cal } \\
\text { Result }\end{array}$} & \multicolumn{3}{|c|}{$\begin{array}{c}\text { Network Output Euro } \\
\text { Code }\end{array}$} \\
\hline & & & $\begin{array}{c}6 \\
\text { nodes }\end{array}$ & $\begin{array}{c}8 \\
\text { nodes }\end{array}$ & $\begin{array}{c}10 \\
\text { nodes }\end{array}$ & & & $\begin{array}{c}6 \\
\text { nodes }\end{array}$ & $\begin{array}{c}8 \\
\text { node }\end{array}$ & $\begin{array}{c}10 \\
\text { nodes }\end{array}$ \\
\hline \multirow{4}{*}{1} & $\mathrm{f}_{\mathrm{ck}}=25$ & \multirow{2}{*}{$b=162$} & \multirow{2}{*}{162.6} & \multirow{2}{*}{162.1} & \multirow{2}{*}{161.53} & $\mathrm{f}_{\mathrm{ck}}=25$ & \multirow{2}{*}{$b=166.8$} & \multirow{2}{*}{166.1} & \multirow{2}{*}{164.0} & \multirow{2}{*}{163.9} \\
\hline & $f_{y}=250$ & & & & & $f_{y}=235$ & & & & \\
\hline & $P_{u}=100$ & \multirow{2}{*}{$\begin{array}{c}\text { Ast }= \\
714.28\end{array}$} & \multirow[t]{2}{*}{714.6} & \multirow[t]{2}{*}{714.1} & \multirow[t]{2}{*}{713.81} & $P_{u}=100$ & \multirow{2}{*}{$\begin{array}{c}\text { Ast }=489 . \\
3\end{array}$} & \multirow[t]{2}{*}{489.1} & \multirow[t]{2}{*}{488.6} & \multirow[t]{2}{*}{487.2} \\
\hline & $\mathrm{m}=8$ & & & & & $\mathrm{~m}=8$ & & & & \\
\hline \multirow{5}{*}{2} & $\mathrm{f}_{\mathrm{ck}}=30$ & \multirow{3}{*}{$\mathrm{b}=158$} & \multirow{3}{*}{158.8} & \multirow{3}{*}{158.1} & \multirow{3}{*}{157.81} & $\mathrm{f}_{\mathrm{ck}}=30$ & \multirow{3}{*}{$\mathrm{b}=158.56$} & \multirow{3}{*}{158.3} & \multirow{3}{*}{157.8} & \multirow{3}{*}{156.5} \\
\hline & & & & & & & & & & \\
\hline & $f_{y}=415$ & & & & & $f_{y}=275$ & & & & \\
\hline & $\mathrm{P}_{\mathrm{u}}=100$ & Asc & 124 & ת & 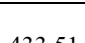 & $\mathrm{P}_{\mathrm{u}}=100$ & Ast $=418$. & 4170 & 4175 & 4164 \\
\hline & $\mathrm{m}=6$ & $=434.7$ & 434.0 & 452.0 & 453.01 & $\mathrm{~m}=6$ & 1 & 417.9 & 417.5 & 410.4 \\
\hline & $\mathrm{f}_{\mathrm{ck}}=35$ & $\mathrm{~b}=$ & & & & $\mathrm{f}_{\mathrm{ck}}=35$ & & & & \\
\hline & $f_{y}=500$ & 151.3 & 151.1 & 150.0 & 149.20 & $f_{y}=355$ & $D^{-}$ & 151.9 & 151.4 & 150.0 \\
\hline & $\mathrm{P}_{\mathrm{u}}=$ & $\mathrm{Asc}=$ & 2624 & 2620 & $36+2>$ & $\mathrm{P}_{\mathrm{u}}=100$ & Ast $=323$. & 323.7 & 323.2 & 8 \\
\hline & $\mathrm{m}=7$ & 363. & 503.4 & 502.9 & 501.0 & $\mathrm{~m}=7$ & 9 & 1 & 3 & 321.0 \\
\hline & $\mathrm{f}_{\mathrm{ck}}=40$ & & & & & $\mathrm{f}_{\mathrm{ck}}=40$ & & 139.3 & 138.8 & \\
\hline & $f_{y}=550$ & & & (J) & (150.0 & $\mathrm{f}_{\mathrm{y}}=420$ & ניכ. & 61 & 8 & 150.0 \\
\hline & $\mathrm{P}_{\mathrm{u}}=$ & $\mathrm{Asc}=$ & & & & $\mathrm{P}_{\mathrm{u}}=100$ & Ast $=273$. & 237.6 & 237.1 & \\
\hline & $\mathrm{m}=6$ & 333.33 & (1) & (JJZ.0 & (301.20 & $\mathrm{m}=6$ & 80 & 1 & 3 & 271.1 \\
\hline
\end{tabular}

\subsection{Theoretical results:}

The influence of grades of steel and concrete on the required quantities of these two materials and on the total cost, including the cost of the formwork of the RC tension members is given in Figures 4-11 


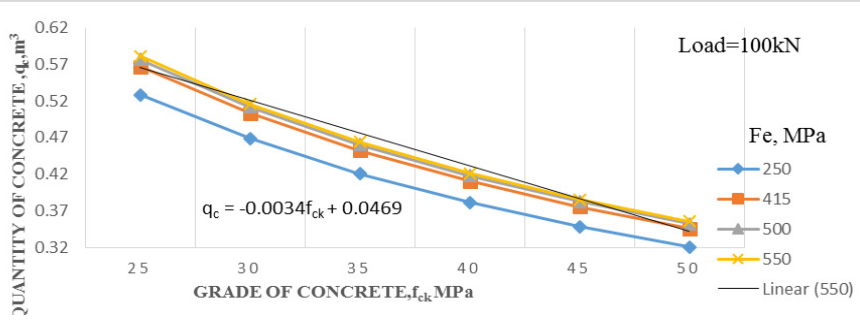

Fig. 4. Variation of Concrete volume with grades of Steel and Concrete.

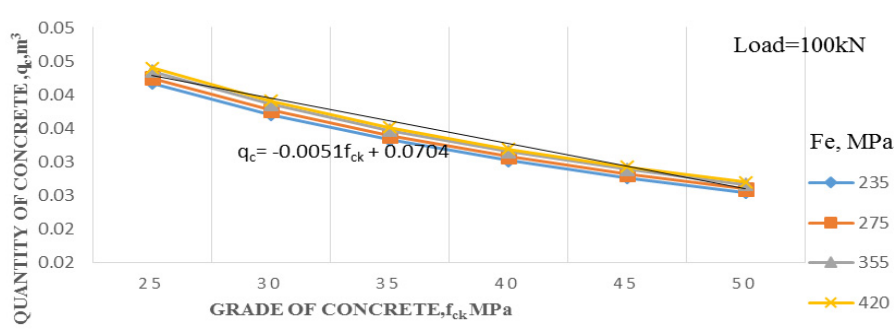

Fig. 5. Variation of Concrete volume with grades of Steel and Concrete.

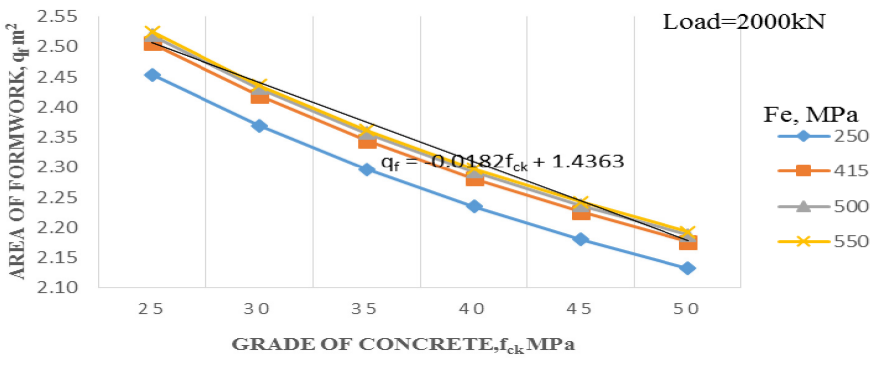

Fig. 6. Variation of area of formwork with grades of Steel and Concrete. 


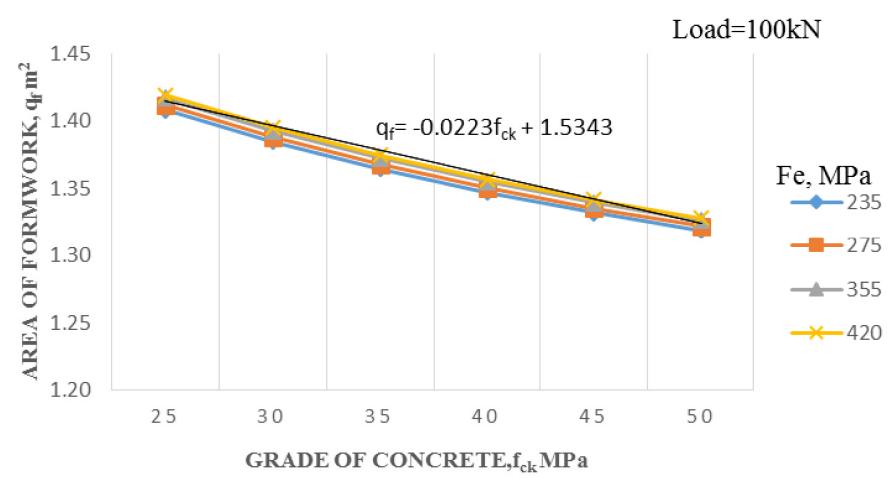

Fig. 7. Variation of area of formwork with grades of Steel and Concrete.

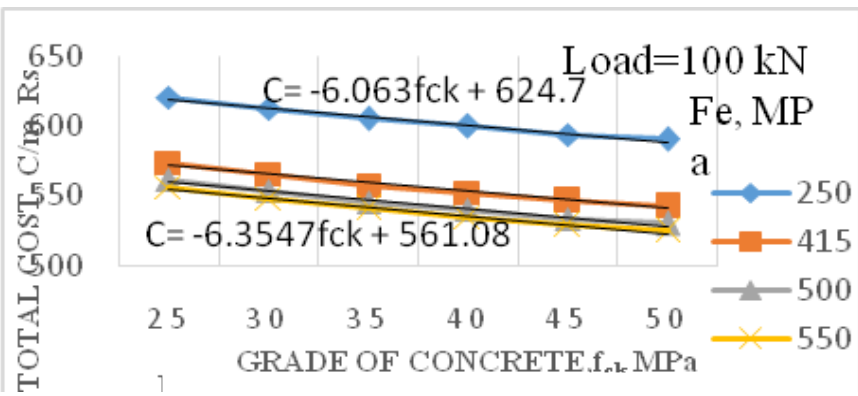

Fig. 8. Variation of Total Cost with grades of Steel and Concrete.

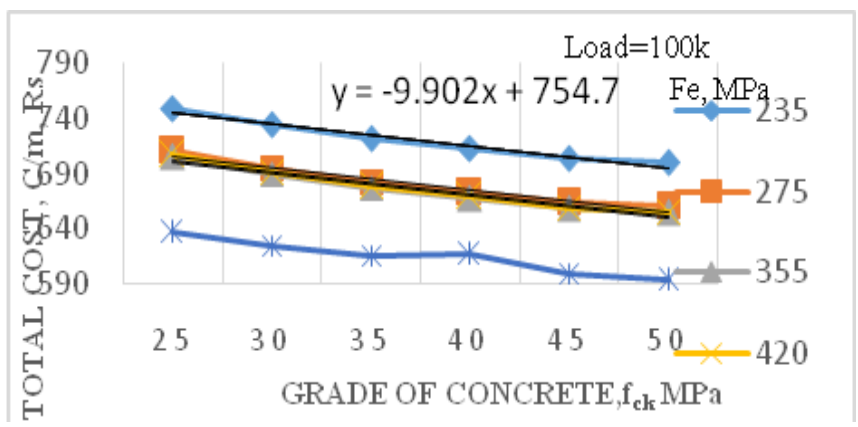

Fig. 9. Variation of Total Cost with grades of Steel and Concrete. 


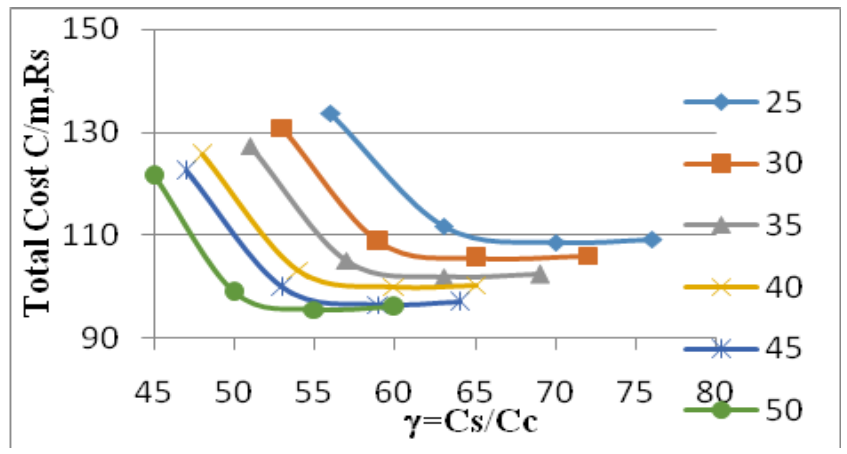

Fig. 10. Variation of Total Cost with $\gamma$.

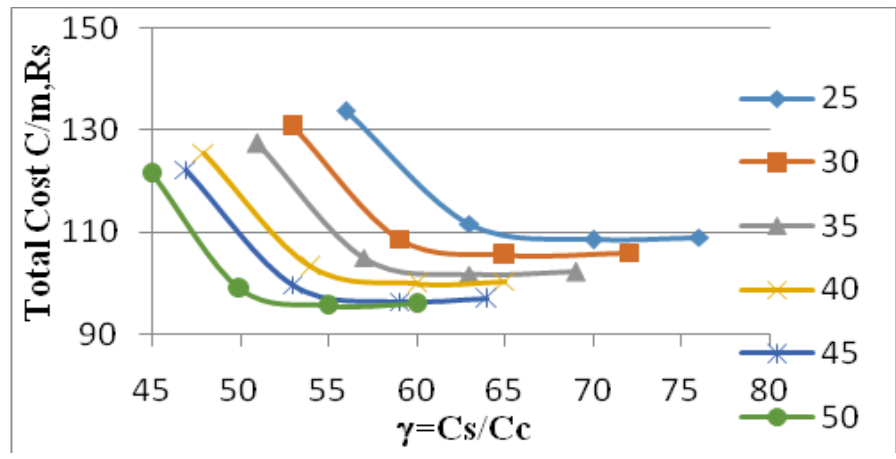

Fig. 11. Variation of Total Cost with $\gamma$. 


\section{REFERENCES}

1. AbobakA.A.Aga, FathelrahmanM.Adam, “Design optimization of Reinforced concrete Frames" Open Journal of Civil Engineering, Volumn 5,ppNo:74-83, doi:10.4236/ojce.2015.51008,ISSN No:Online: 2164-3172, 2015.

2. S.K. Anand Prakash, K.K. Agarwala Singh, "Optimum design of reinforced concrete sections", Computers and Structures, Volume30,Issue 4, pp.No 1009-1011, http://dx.doi.org/10.1016/0045-7949(88)90142-3, ISSN: 0045-7949, 1988.

3. ArunlfoLuevanos-Rojas, "Numerical experimentation for the optimal design of reinforced rectangular concrete beams for singly reinforced sections “, DYNA 83(196),pp.No.134-142, 2016.

4. P.K. Balachandra, S.Adsul., "Cost Optimization Of Doubly Reinforced Rectangular” International journal of Modern Engineering Research (IJMER)- Vol 2 Issue 5,pp.3939-3942, 2012.

5. Beams by Neural Networks, ASCE Journal of Structural Engineering, Vol. 127, No. 7, 2001,pp. 818-828.

6. Chakarnatty "Model for Optimal Design of Reinforced Concrete Beam" Journal of Structural Engineering Vol 118 (3) pp.No:447-451, 1992.

7. G. Preethi, Prince G. Arulraj “Optimal Design of Axially Loaded RC Column”, Bonfring International journal of Industrial Engineering and Management Science, Vol 6 No.3 pp.No.78-81, 2016.

8. N.S. Hadi, Neural Networks Applications in Concrete structures, Computers and Structures, Vol. 81, pp.373$381,2002$.

9. H. Sudarsana Rao, B. Ramesh Babu, "Optimized column design using genetic algorithm based neural networks” Indian Journal of Engineering \& Materials Sciences, Vol 13, pp.No 503-511, 2006.

10. ImaRahmanian, YvesLucet, Solomon Tesfamariam "Optimal Design of reinforced concrete beams:Areview", Computers and Concrete"Vol.13,No.4, ppNo.457-482, 2014.

11. Luisa Mari a Gil-Martin Mark Aschheim Enrique Hernandez-Montes Mark Aschheim, "Optimal reinforcement of RC columns for biaxial bending" Matrials and Structures, pp.no 1245-1256, 2010.

12. S. Mehta, "Cost Optimization of Concrete Beam Element - By Direct Exhaustive Search Method", Indian Journal of Engineering \& Materials Sciences Vol. 13, pp. 503-511, 2006.

13. M.Z. Cohn "limit state design of reinforced concrete structures for maximum yield safety:, Indian Concrete Journal, Vol. 36, No.6, 1962.

14. M. Papadrakakis, N.D. Lagaros, "Soft Computing Methodologies for Structural optimization", Applied soft computing Vol (3), pp.283-300,2003

15. Salim T Yousif, Ikhlas S ALsaffar, Saddam M.Ahmed, "Optimum Design of Singly and Doubly Reinforced Concrete rectangular beam sections: Artificial Neural Network", Iraqi journal of Civil Engineering, Volume 6 No.3, 2010.

16. A. SaraBabiker, M. Fathelrahman. E. Abdelrahman, “ Design Optimization Of Reinforced Concrete Beams Using Artificial Neural Network” International Journal of Engineering Inventions, Volume 1, Issue 8,PP: 0713, 2012.

17. Sinan Melih Nigdeli, Gebrail Bekdaş,"Optimum design of RC continuous beams considering unfavorable liveload distributions" KSCE Journal of Civil Engineering, Vol 20, Issue112, pp No. 1-7, 2016.

18. V.PETCU:" Optimal plastic moments reinforced concrete continuous beams" Indian Concrete Journal, V.36, No.3, March 1962, pp.110-113.

19. T. Yousif., M. Ahmed, "Optimum Design of Singly and Doubly Reinforced Concrete Rectangular Beam Sections: Artificial Neural Networks Application “,Iraqi Journal of Civil Engineering Vol. 6, No. 3, pp. 1-19, 2006.

20. N. KarthigaShenbagam, Dr.N. Arunachalam "Least Cost Design of Axially Loaded Tension Members using Optimization Techniques" International Journal of Printing Packing and Allied Sciences, Volume 4 Issue 2, page No.1250-1259, 2016.

21. Ashok K Jain, Reinforced concrete Limit state design, Nem Chand \& Bros, Roorkee, 2010.

22. B.C.Punmia, Ashok K Jain,Arun Kr Jain, Limit State Design of Reinforced concrete,Firewall Media,2007

23. Davis, L. Hand book of genetic algorithms. Van NostrandReinholt, New York. 1991.

24. Design Expert Systems, Computers and Structures, Vol. 54, No. 3,1995,pp. 367-375.

25. N. Krishnaraju, Advanced Reinforced concrete design, CBS Publishers and Distibutors, New Delhi, Bangalore, 2009

26. N. Krishnaraju, Reinforced concrete design, CBS Publishers and Distibutors, New Delhi, Bangalore, 2009.

27. A. Mukharjee, Deshpande., Application of Artificial Neural Networks in Structural

28. Mishra, A.K., \&AkhilUpadhyay., Compression Design using ANN, ICI Journal, 2004, pp. 17-19.

29. Nilson,Darwin and Dolan, "Design of Concrete Structures:, McGraw-Hill, $13^{\text {th }}$ Edition,2004.

30. N.Subramanian,Design of Reinforced concrete Structures, Oxford University Press, 2013

31. P.C.Varghese, Limit State Design of Reinforced concrete Structures,Prentice Hall of India Private Limited, 2008 
32. Rao S.S, Engineering Optimization Theory and Practice, New Age International publisher, 2009

33. S.Unnikrishnan Pillai, DevadosMenon, "Reinforced concrete Design Third edition Tata McGraw Hill,2009

34. The math works, MATLAB V6.5,24 prime way, Natick, MA 01760-1500,USA,2002.

35. ACI Committee 318, Building Code Requirements for Reinforced Concrete, American Concrete Institute, Detroit 2005.

36. EN1992 I-I and EN1992-I-2, EUROCODE 2: Design of Concrete Structures Design of Concrete Structures General Rules and rules for Buildings and Structural Fire Design.

37. IS456:2000, Code of Practice foe Plain and Reinforced Concrete, Bureau of Indian Standards, New Delhi

38. SP16:1980:Design Aids for IS456:2000

\section{LIST OF FIGURES AND TABLES:}

Fig. 1. Neural Network model with 10 nodes.

Rys. 1. Model sieci neuronowej z dziesięcioma węzłami

Fig.2. Neural Network model with 8 nodes.

Rys. 2. Model sieci neuronowej z ośmioma węzłami

Fig.3. Neural Network model with 6 nodes.

Rys. 3. Model sieci z sześcioma węzłami

Fig.4. Variation of concrete volume with grades of steel and concrete.

Rys. 4 Wariacja objętości betonu w zależności od klasy stali i betonu.

Fig.5. Variation of concrete volume with grades of steel and concrete.

Rys. 5 Wariacja objętości betonu w zależności od klasy stali i betonu.

Fig.6. Variation of area of formwork with grades of steel and concrete.

Rys. 6 Wariacja obszaru szalowania w zależności od klasy stali i betonu.

Fig.7. Variation of area of formwork with grades of steel and concrete.

Rys. 7 Wariacja obszaru szalowania w zależności od klasy stali i betonu.

Fig.8. Variation of Total cost with grades of steel and concrete.

Rys. 8 Wariacja kosztu całkowitego w zależności od klasy stali i betonu.

Fig.9. Variation of Total cost with grades of steel and concrete.

Rys. 9 Wariacja kosztu całkowitego w zależności od klasy stali i betonu.

Fig.10. Variation of Total cost with $\gamma$.

Rys. 10 Wariacja kosztu całkowitego w zależności od $\gamma$.

Fig.11. Variation of Total cost with $\gamma$.

Rys. 11 Wariacja kosztu całkowitego w zależności od $\gamma$.

Tab. 1. Results obtained from actual and neural network models.

Tab. 1. Wyniki uzyskane z rzeczywistego modelu i modelu sieci neuronowej 


\section{PORÓWNANIE OPTYMALNYCH KOSZTÓW OSIOWO OBCIĄŻONYCH ZBROJONYCH CIĘGIEN Z WYKORZYSTANIEM STANDARDÓW EUROPEJSKICH I INDYJSKICH}

Slowa kluczowe - zbrojone cięgna, optymalna konstrukcja, optymalizacja, obciążenia, sieci neuronowe, model projektowy, standardy indyjskie, standardy europejskie.

Niniejsza praca została poświęcona optymalnemu projektowi zbrojonych cięgien. Zaprojektowano blisko pięćset zbrojonych cięgien zgodnie ze standardem indyjskim IS 456:2000 i standardem europejskim EN1992, ręcznie przy użyciu arkuszy kalkulacyjnych Microsoft Excel. Uwzględnione zmienne stanowią charakterystyczną wytrzymałość betonu, wahającą się od 25 do $50 \mathrm{~N} / \mathrm{mm}^{2}$ dla obu specyfikacji kodału? (codal?). Wytrzymałość plastyczna stali waha się pomiędzy $250,415,500$ i $550 \mathrm{~N} / \mathrm{mm}^{2}$ w przypadku IS 456:2000 i pomiędzy 235, 275, 355, 420 i $460 \mathrm{~N} / \mathrm{mm}^{2}$ w przypadku standardu europejskiego. Obciążenie osiowe wahało się od $500 \mathrm{kN}$ do $3000 \mathrm{kN}$. Teoretyczne wyniki uzyskane na podstawie ręcznego projektu zostały wyjaśnione poniżej.

Na podstawie Rysunku 4 i 5 można stwierdzić, że wraz ze wzrostem klasy betonu, wymagana objętość betonu maleje, a wariacja staje się nieliniowa. W przypadku stali Fe 250, wariacja może być przybliżona za pomocą linii prostej o następującym równaniu: $\mathrm{q}_{\mathrm{c}}=-0.0034 \mathrm{f}_{\mathrm{ck}}+0.0469 \mathrm{w}$ oparciu o IS 456:2000, natomiast dla standardu europejskiego, równanie jest następujące: $\mathrm{q}_{\mathrm{c}}=-0.002 \mathrm{f}_{\mathrm{ck}}+0.027$. Oczywisty jest również fakt, że wymagana objętość betonu dla konkretnej klasy betonu wzrasta wraz ze wzrostem klasy stali.

Na podstawie Rysunku 6 i 7 można stwierdzić, że wraz ze wzrostem klasy betonu, wymagany obszar szalowania się zmniejsza, ponieważ rozmiar cięgien się zmniejsza, a wariacja staje się nieliniowa. Dla klasy stali Fe 415, 500 i 550, wariacja może być przybliżona za pomocą linii prostej o następującym równaniu: $\mathrm{q}_{\mathrm{f}}=-0.0182 \mathrm{f}_{\mathrm{ck}}+1.4363$. $\mathrm{W}$ przypadku standardu europejskiego, równanie jest następujące: $\mathrm{q}_{\mathrm{f}}=-0.014 \mathrm{f}_{\mathrm{ck}}+1.351$

Na podstawie Rysunku 6 można stwierdzić, że wraz ze wzrostem klasy betonu, koszt konstrukcji cięgna zbrojonego maleje, zgodnie z poniższymi równaniami:

$\mathrm{C}=-6.063 \mathrm{fck}+624.7 \quad$ dla klasy stali Fe250

$\mathrm{C}=-6.2773 \mathrm{fck}+578.04$ dla klasy stali Fe415

$\mathrm{C}=-6.3316 \mathrm{fck}+566.14$ dla klasy stali Fe500

$\mathrm{C}=-6.354 \mathrm{fck}+561.08$ dla klasy stali Fe550

Na podstawie Rysunku 7 można stwierdzić, że wraz ze wzrostem stosunku $\gamma$ kosztów stali do kosztów betonu, koszt konstrukcji cięgna zbrojonego maleje dla różnych klas betonu.

Na podstawie podejścia teoretycznego i podejścia ANN zastosowanych przez autorów, stwierdzono, że:

1. Wraz ze wzrostem klasy betonu, wymagana objętość betonu maleje, wnioski są wyciągane, a wymagany obszar szalowania się zmniejsza.

2. Wraz ze wzrostem klasy betonu, całkowity koszt cięgna zbrojonego maleje.

3. Wraz ze wzrostem wartości $\gamma$, koszt konstrukcji cięgna zbrojonego maleje dla wszystkich klas betonu.

4. Wraz ze wzrostem klasy stali, koszt konstrukcji (koszt betonu i stali) cięgna zbrojonego maleje.

5. Wraz ze wzrostem klasy betonu, koszt cięgna zbrojonego maleje. 
Sztuczna inteligencja jest dziedziną nauki, która obejmuje badania, projektowanie oraz zastosowanie sztucznej inteligencji w dziedzinie informatyki. Tradycyjne metody modelowania i optymalizacji złożonych systemów strukturalnych wymagają ogromnych zasobów komputerowych, jak również problemów związanych ze sztuczną inteligencją, które często mogą stanowić cenne alternatywy dla skutecznego rozwiązywania problemów inżynierii lądowej. Niniejsza praca zawiera krótki opis ostatniej opracowanej metody i teorii w rozwijającym się kierunku zastosowań sztucznej inteligencji w inżynierii lądowej, takie jak obliczenia ewolucyjne, sieci neuronowe, rozmyte systemy, systemy eksperckie, rozumowanie, klasyfikacja i nauka, jak również inne, takie jak teoria chaosu, algorytm „cuckoo search”, algorytm „firefly”, inżynieria oparta na wiedzy oraz symulowane wyżarzanie. Praca zawiera przegląd postępów w zakresie sztucznej inteligencji oraz jej zastosowania w inżynierii lądowej.

ANN jest zbiorem systemu opartego na działaniu biologicznych sieci neuronowych. Dane wejściowe są przesyłane do sieci neuronowej i uzyskuje się odpowiednią pożądaną docelową odpowiedź. Błąd składa się z różnicy pomiędzy pożądanym wyjściem i wejściem systemu. W niniejszej pracy, metoda wstecznej propagacji ANN została wykorzystana w celu określenia optymalnej wartości funkcji kosztów.

Projektant konstrukcji ma na celu znalezienie optymalnego rozwiązania dla projektu konstrukcji. Optymalne rozwiązanie dla całkowitego kosztu konstrukcji cięgien zbrojonych jest związane z sumą trzech kosztów, takich jak koszt betonu, koszt stali oraz koszt szalowania. Dzięki zastosowaniu nietradycyjnych technik, takich jak ANN, zmiennych wejściowe, które stanowiły charakterystyczną wytrzymałość betonu i stali, obciążeniu cięgna zbrojonego oraz wartości stosunku modularnego, ukryte warstwy zostały zmienione na trzy typy, takie jak sześć węzłów, osiem węzłów i dziesięć węzłów, odpowiednio. Funkcja wagi jest obliczana i normalizowana. Wartości wejściowe są badane w celu uzyskania optymalnej wartości dla powierzchni przekroju brutto i stali. Wreszcie, na podstawie różnych badań ukrytych węzłów stwierdzono, że wraz ze wzrostem liczby ukrytych węzłów uzyskujemy bardziej optymalną wartość w porównaniu z rzeczywistym projektem w standardzie indyjskim iS456:2000 i standardzie europejskim. Wyniki uzyskane w oparciu o wyjścia generowane przez sztuczne modele sieci neuronowych, w odniesieniu do wyników teoretycznych, okazały się mieścić w zadowalającym zakresie. Zbadano wpływ klasy betonu i stali na całkowity koszt cięgien zbrojonych i wyciągnięto wnioski przydatne dla praktycznych zastosowań. 